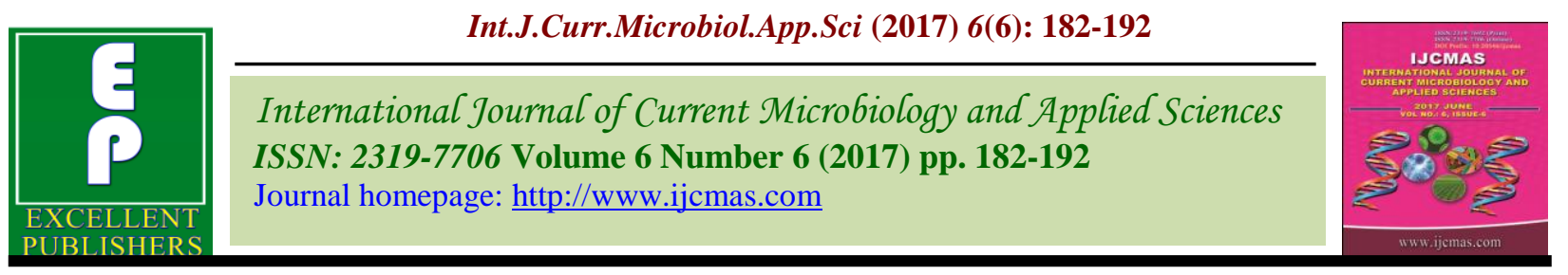

Original Research Article

https://doi.org/10.20546/ijcmas.2017.606.022

\title{
Analysis of Short-Term Droughts in the Mewar Region of Rajasthan by Standard Precipitation Index
}

\author{
K.A. Basamma ${ }^{1 *}$, R.C. Purohit ${ }^{1}$, S.R. Bhakar ${ }^{1}$, Mahesh Kothari ${ }^{1}$, R.R. Joshi ${ }^{2}$, \\ Deepak Sharma ${ }^{3}$, P.K. Singh ${ }^{1}$ and H.K. Mittal ${ }^{1}$ \\ ${ }^{1}$ Department of Soil and Water Engineering, CTAE, Udaipur - 313 001, India \\ ${ }^{2}$ Department of Electrical Engineering, CTAE, Udaipur-313 001, India \\ ${ }^{3}$ Department of RES, CTAE, Udaipur-313 001, India \\ *Corresponding author
}

\begin{tabular}{|c|c|}
\hline & A B S T R A C T \\
\hline $\begin{array}{l}\text { Ke y w or d s } \\
\text { Standardized } \\
\text { precipitation } \\
\text { index, Short term, } \\
\text { Spatial } \\
\text { and temporal. }\end{array}$ & $\begin{array}{l}\text { Agricultural drought has become a prime concern worldwide because of its } \\
\text { severe effect on productivity of rain-fed crops and indirect effect on } \\
\text { employment as well as per capita income. These agricultural droughts } \\
\text { occur due to short term moisture stresses. This work was carried out to } \\
\text { analyze droughts in the Mewar region of Rajasthan using Standardized } \\
\text { Precipitation Index (SPI). SPI_1 and SPI_3 which are representatives of }\end{array}$ \\
\hline Article Info & $\begin{array}{l}\text { short term drought are used for analysis. Its application can be related } \\
\text { closely to meteorological types of drought along with short-term soil }\end{array}$ \\
\hline $\begin{array}{l}\text { Accepted: } \\
\text { 04 May } 2017 \\
\text { Available Online: } \\
\text { 10 June } 2017\end{array}$ & $\begin{array}{l}\text { moisture and crop stresses. Efforts have been made in monitoring the } \\
\text { temporal and spatial extent of drought in the region. Study indicated that } \\
\text { region affected by short term droughts frequently in the past three decades. }\end{array}$ \\
\hline
\end{tabular}

\section{Introduction}

Drought is an insidious hazard of nature; it affects more people than any other form of natural catastrophe. It is world's most expensive natural disaster causing an estimated loss of between $\$ 6$ and $\$ 8$ billion USD each year globally (Keyantash et al., 2002). Drought manifests itself as a regional entity rather than a local event which often covers large areas extending across several catchments or river basins. So the spatial extent and temporal aspects such as a drought's persistence are considered important characteristics of the drought event
(Andreadis et al., 2005; Hisdal et al., 2003) beside the characteristics such as severity and duration of a drought, the National Commission on Agriculture in India defines three types of droughts namely, meteorological, agricultural and hydrological droughts. Meteorological drought is defined as a situation when there is significant decrease from normal precipitation over an area (i.e. more than $25 \%$ ). Agricultural drought occurs when rain fall and soil moisture become inadequate during the growing season to support healthy crop 
growth to maturity and causes crop stress and wilting. Hydrological droughts occur when meteorological droughts last for long time eventually lead to situations like drying up of reservoirs, lakes, streams and rivers and fall in groundwater level (NRSC, 2008). By seeing the changes in meteorological and hydrological conditions influencing and threatening the reduction of supply of some goods and services such as energy, food and drinking water, American Meteorological Society (1997) introduced another drought category called socio-economic drought (American Meteorological Society, 1997).

Agriculture is the immediate victim of drought disaster - impacting crop area, crop production and farm employment (Rathore et $a l ., 2014)$. In India more than $68 \%$ people are directly and indirectly dependent upon agriculture (Jain et al., 2010). About 68\% in net sown area of 140 million hectares is vulnerable to drought conditions and about $50 \%$ of such vulnerable area is classified as 'severe', where frequency of drought is almost regular. The 2002 drought reduced the sown area to 112 million hectares from 124 million hectares. According to (Murthy et al., 2010), the 1987 drought in India damaged 58.6 million hectares of cropped area affecting over 285 million people. The 2002 drought reduced food grain production to 174 million tons from 212 million tons, thus leading to a 3.2 per cent decline in agricultural GDP. So agricultural drought plays a major role in the economy of agrarian countries like India, when drought occurs it makes the land incapable of cultivation throughout the year and this situation creates harsh and unfriendly environmental condition for human being, livestock population, biomass potential and plant species (Siddiqui, 2004). So, there is an urgent need to make an effort to monitor and mitigate drought disaster with reference to span of time (Rathore, 2004). A well designed mitigation and preparedness plan can help the decision makers to reduce the effect of drought. In this context, the present study attempts to assess agricultural drought by using Standard Precipitation Index (SPI) and GIS techniques for monitoring the spatio-temporal extent of agricultural drought in Mewar region of Rajasthan.

\section{Materials and Methods}

\section{Study area}

When we hear about Rajasthan first thing that comes to mind is it has deserts and deserts are formed due to low rainfall resulting in scarcity of water. That's true to most extent because out of 13 states repeatedly declared as drought-prone, Rajasthan is the most critical state in the country with highest probabilities of drought occurrence and rainfall deficiencies (Rathore, 2005). In more recent times, Rajasthan has experienced severe and frequent spells of droughts than any other region in India. According to study conducted by state control board Rajasthan is likely to suffer from further increase in water shortages due to overall reduction in rainfall and increase in evapotranspiration as consequences of global warming (Rathore $e t$ al., 2013).

Mewar region which is selected as a Study area is located south of the Great Indian Desert of Rajasthan, India with total area of $34437 \mathrm{~km} 2$. Located between 72059 ' 32' 'E to $75049^{\prime} 21^{\prime \prime}$ 'E longitude to 23047 ' $55^{\prime \prime}$ ' $\mathrm{N}$ to 25 57' 58', N latitude and encompasses, broadly the districts of Rajsamand, Udaipur, Bhilwara and Chittorgarh (Fig. 1). Climatically the region is transitional between sub-humid in south-east to semi-arid in north, north-west. The annual range of temperature varies from a maximum of $23.10^{\circ} \mathrm{C}$ in January and $37.43^{\circ} \mathrm{C}$ in May. The mean temperatures range for January and May are 
$17.13^{\circ} \mathrm{C}$ to $34.36^{\circ} \mathrm{C}$, respectively (Rathore, 2011). Rainfall in the region is characterized by moderate amount, seasonality, limited number of rainy days but with a larger number of cloudy days, variability in terms of time and space, uncertainty and unreliability again regarding time, space and amount. Rainfall averages $660 \mathrm{~mm} /$ year and is generally higher in the southwest and lower in the northeast of the region. Over $90 \%$ of the rain typically falls in the period June to September every year, during the southwest monsoon (Rathore, 2010).

\section{Data acquisition and Methodology}

The monthly rainfall data for the period of 34 years (1981-2014) of 17 rain gauge stations located in the Mewar was collected from the website of Water Resource Department, Rajasthan. Distribution of rain gauge stations in study area is given in figure 1 .

\section{Spatial interpolation of rainfall}

Since rainfall is never evenly distributed over the area of study due to the topographic variability of the catchment areas, hydrologists are frequently required to estimate point rainfall at unrecorded locations from measurements at surrounding sites. Optimizing rain gauge network design and selecting an appropriate interpolation method requires knowledge of rainfall spatial variability. The spatial explicit data are often obtained by geostatistical methods. Among a large number of interpolation algorithms, geostatistical methods are widely used. Geostatistical methods allow the interpolation of spatially referenced data and the prediction of values for arbitrary points in the area of interest (Nohegar et al., 2013). In this study, IDW approach is used for spatial interpolation of rainfall and drought characteristics over the Mewar region (Mishraet al., 2005). Total area of Mewar region is divided into grids of $30 \times$
30 (Figure 1). Monthly rainfall recorded at 17 stations for 34 years (1981-2014) were interpolated by ArcGIS 9.3, using Inverse Distance Weighing (IDW) algorithm and gridded monthly rainfall was created. Mean monthly areal rainfall of region was estimated by averaging gridded rainfall to find out the regional representative of SPI, assessing the regional behavior of drought characteristics. Gridded monthly rainfall data was used for the estimation of the SPI at each grid for each month of the period of analysis at multiple time scales for assessing the spatial extent of drought characteristics in the region in terms of percent of area affected (Manikandan et al., 2015).

\section{Standardized Precipitation Index (SPI)}

Drought assessment involves thorough understanding of variations of its characteristics over time. Drought Index (DI) is a significant indicator which assists to assess the effect of drought and different drought characteristics viz., Intensity, duration, Severity and Spatial extent in terms of numerical numbers which are believed to be far more functional than raw data. DI helps in sizing and quantifying drought condition. DI gives information of drought in numerical figures and it is most widely used drought assessment tool besides many other tools. Drought Indices are effective during decision making (Hayes, 2003) in the events such as to initiate drought relief programs, to measure the deficits of water in water resources, to assess drought severity etc. Various indices were introduced by researchers, PDSI (Palmer, 1965), Deciles (Gibbs et al., 1967), SPI (McKee et al., 1993), PN (Willeke et al., 1994), SWSI (Shafer et al., 1982), ADI (Keyantash et al., 2004) and NADI (Barua, 2010).

The Standardized Precipitation Index (SPI) is developed by McKee et al.,, (1993) at 
Colorado State University, US to quantify precipitation deficits on multiple time scales. Soil moisture conditions respond to precipitation anomalies on a relatively short scale.

Groundwater, streamflow, and reservoir storage reflect the longer-term precipitation anomalies. For these reasons, McKee et al., (1993) originally calculated the SPI for 1,3 , $6,12,24$, and 48 month time scales. SPI is recommended by the World Meteorological Organization as a standard to characterize meteorological droughts (Dutra et al., 2013). SPI values can be categorized according to classes (Table 1). SPI values are positive or negative for greater or less than mean precipitation, respectively. Procedure for computation of SPI can be found in (Mishra et al., 2005). In this study, an SPI program, SPI_SL_6, developed by the National Drought Mitigation Centre (NDMC) at the University of Nebraska-Lincoln, was used to compute time series of Standard Precipitation Index.

\section{Temporal and spatial analysis of drought}

Occurrence of drought categories and monthly distribution of occurrence of drought categories were determined from the regional representative of SPI series. Drought parameters (most intense quantity of drought, onset and end time of drought, drought duration, drought severity and drought frequency) were determined based on the theory of runs proposed by (Belayneh, 2012). Percentage of drought occurrence was calculated by taking the ratio of drought occurrences in each drought category to the total drought occurrences for each grid. Monthly distribution of occurrence of drought categories were calculated by taking the ratio of number of drought occurrence in each category in each month to total number of months over the period of analysis (Yevjevich, 1967).

\section{Results and Discussion}

The temporal characteristics of short term droughts in Mewar region were analyzed based on the regional representative of SPI value to assess the regional drought. A regional drought characters i.e. Drought occurrence, most intense, severity, duration, intensity and frequency were studied. Regional representative of monthly SPI values have been computed at 1-month and 3month time scales using mean monthly areal rainfall. Use of different time scales helps to identify different types of drought. In this study SPI_1 and SPI_3 time series values are used to analyze the short duration drought. These (SPI_1 and SPI_3) SPI are useful in monitoring agricultural drought and meteorological drought (Cacciamani et al., 2002). 1-month SPI reflects short-term conditions and it is a good indicator of the deviation of precipitation from the long-term average (Belayneh, 2012). Its application can be related closely to meteorological types of drought along with short-term soil moisture and crop stress, especially during the growing season. A 3-month SPI provides a seasonal estimation of precipitation and it is effective in highlighting available moisture conditions when compared to currently available hydrological indices (Belayneh, 2012).

The 1-month and 3-month SPI values for Mewar region are shown in figures 2 and 3 for periods of 1981-2014. As shown in figures 2 and 3, characteristics of drought change with time (Manikandan et al., 2015). The time series of monthly SPI showed that the region experienced frequent droughts for the period of drought analysis and detected several severe and extreme drought events. These droughts occur more frequently and it assesses the effect of agricultural drought as mentioned earlier. Analysis of the computed SPI series for SPI_1 time scale (Figure 2) showed that Mewar region has experienced 
droughts in terms of severity and duration in the middle of 1980s, start and end of 1990s and initial years of 2000s. Greater than 30 percent of the years under study faced severe and extreme drought in 1-month time scale. Drought which accrued in July 2002 had intensity of -3.83 , which is the most intense drought occurred in the study period and this type of drought is very rare to found. 1987, 2002 and 2000 droughts had peak magnitude of $-5.2,-5.18$ and -4.78 respectively. Longest duration droughts in the study period in 1month time scale occurred in 1984 and 2002 which creped of four months had a substantial impact on the region.

Basedon 3-month SPI values (Figure 3) years 1986-1988, 1990-1994 and 1998-2002 were affected by severe and extreme droughts. Years2002, 1987 and 2000 had peak magnitude of $-9.48,-9.02$ and -8.62 produced a greater impact in the region. In the Mewar 41 percent of the years under study faced severe and extreme droughts at 3-month time scale. As shown in figue SPI responds quickly to wet and dry periods, which means that each new month has a large influence on the period sum of precipitation. This also means more droughts of shorter duration. On the other hand, as the time scale increases, the index responds more slowly. In other words, as the time scale increases, each new month has less impact on the total, which is indicative of fewer droughts of longer duration. The most intense drought i.e., minimum negative of SPI values derived from the regional representative of SPI values over the study period for Mewar region showed that, The most extreme 1-month SPI (SPI 1 $=-3.83$ ) and the 3-month SPI (SPI 3=-2.69) was occurred in July 2002 which were having return period of $>100$ and 35 years, respectively.

\section{Occurrence of drought categories}

Occurrence of drought categories provides convincing answer to the question: "How many droughts have occurred in the Mewar region in the past?" Table 2 presents the percentage of occurrence of drought categories at multiple time scales in the Mewar region. The results showed that for a given time scale mild droughts occur most frequently and extreme droughts occurs least frequently. The percentage occurrence of drought events with drought severity level of mild to extreme drought has nearly comparable values for all time scales. Similar results were reported by (Manikandan et al., 2015; Edossa et al., 2010).

\section{Monthly distribution of drought categories}

The results of monthly distribution of percentage of occurrence of droughts at multiple time scales in the Mewar are presented in table 3 . From the table 3 it can be observed that the Mewar region experienced frequent droughts for all months of the year. Analysis of percentage of occurrence of drought at 1-month SPI showed that April, May and October are the months during which the SPI_1 values most frequently takes the negative SPI value and it is followed by June, August, September and July.

Table.1 Drought Classification based on SPI (McKee et al.,, 1993)

\begin{tabular}{ll}
\hline SPI Values & Class \\
\hline-0.99 to 0.99 & Near normal \\
-1 to -1.49 & Moderately dry \\
-1.5 to -1.99 & Very dry \\
$<-2$ & Extremely dry \\
\hline
\end{tabular}


Table.2 Occurrence of drought categories (percentage) in the Mewar region

\begin{tabular}{ccccccc}
\hline SI.No & Time Scale & Mild & Moderate & Severe & Extreme & Total \\
\hline 1 & SPI_1 & 26.23 & 2.21 & 0.98 & 1.96 & 31.37 \\
2 & SPI_3 & 38.24 & 5.39 & 2.70 & 1.96 & 48.28 \\
\hline
\end{tabular}

Table.3 Monthly distributions of drought categories

\begin{tabular}{lcccccccccccc}
\hline Month & Jan & Feb & Mar & Apr & May & Jun & Jul & Aug & Sep & Oct & Nov & Dec \\
\hline SPI_1 & 0.00 & 0.00 & 0.00 & 8.33 & 4.17 & 3.92 & 3.43 & 3.68 & 3.68 & 4.17 & 0.00 & 0.00 \\
SPI_3 & 4.17 & 4.17 & 4.90 & 4.66 & 3.68 & 4.41 & 3.43 & 3.43 & 3.68 & 3.68 & 3.43 & 4.66 \\
\hline
\end{tabular}

Fig.1 Details of the study area

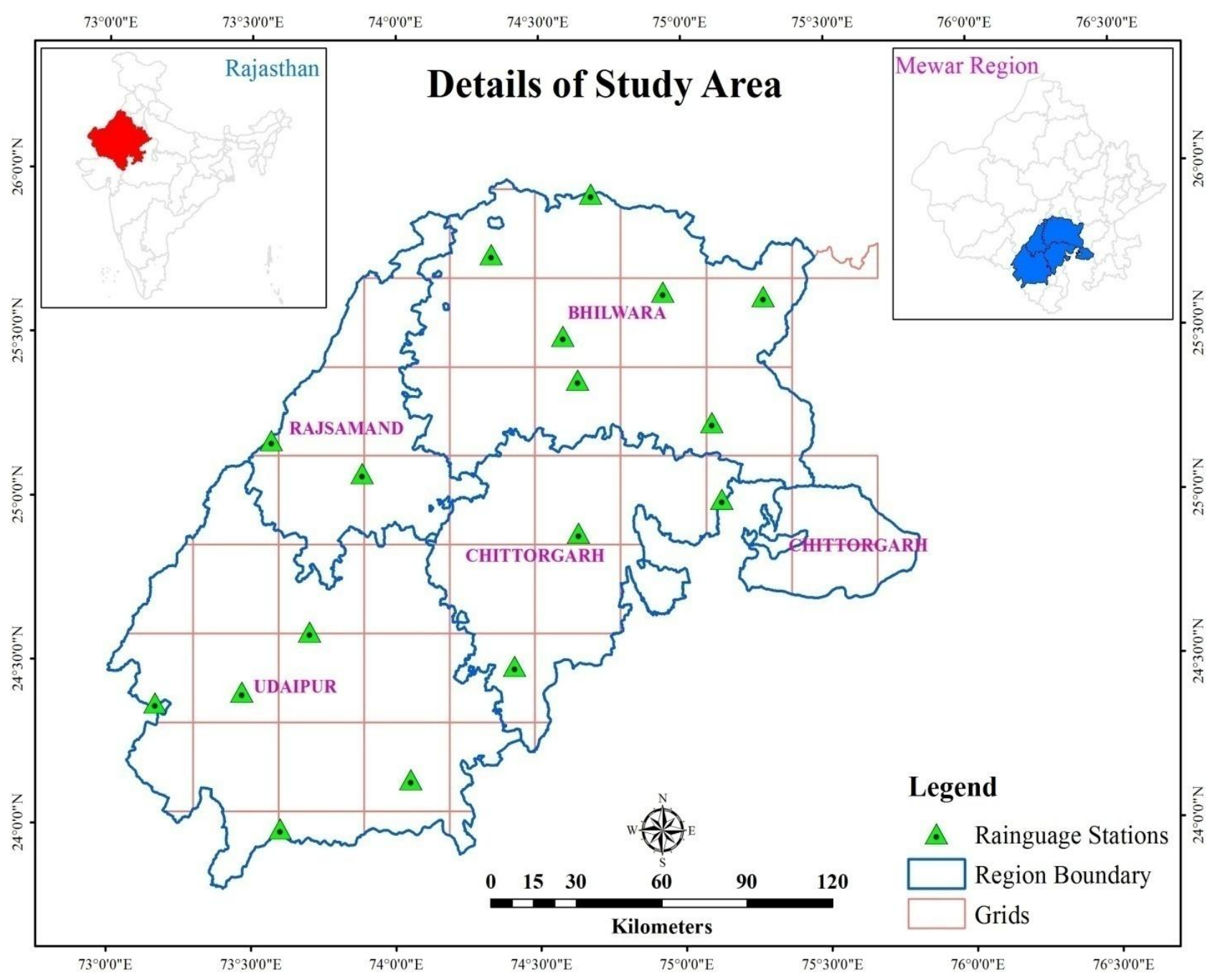


Fig.2 Time series of SPI Values at 1-month timescale for Mewar region

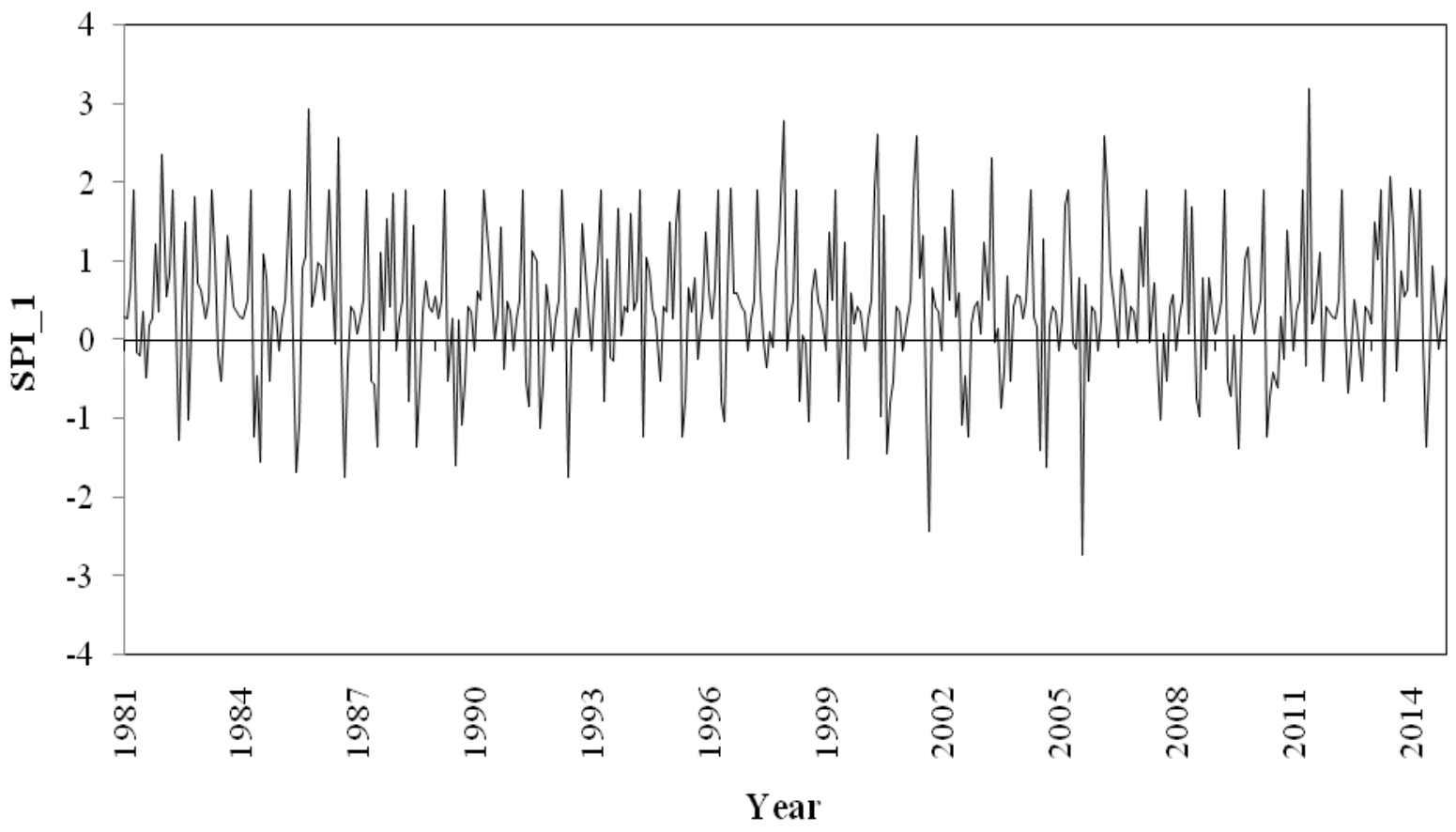

Fig.3 Time series of SPI Values at 3-month timescale for Mewar region

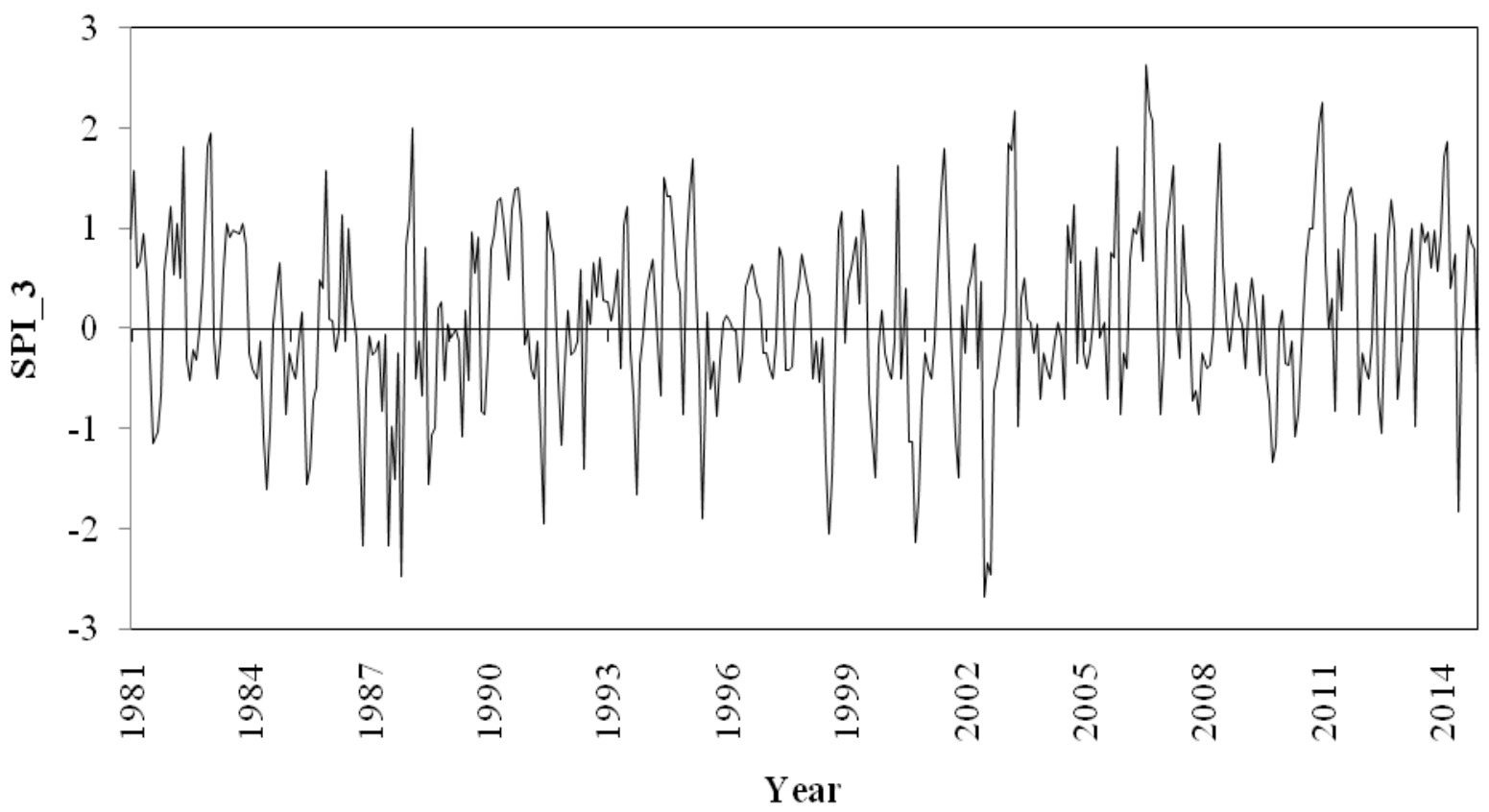


Fig.4 Areal extent of drought categories in 1-month time scale

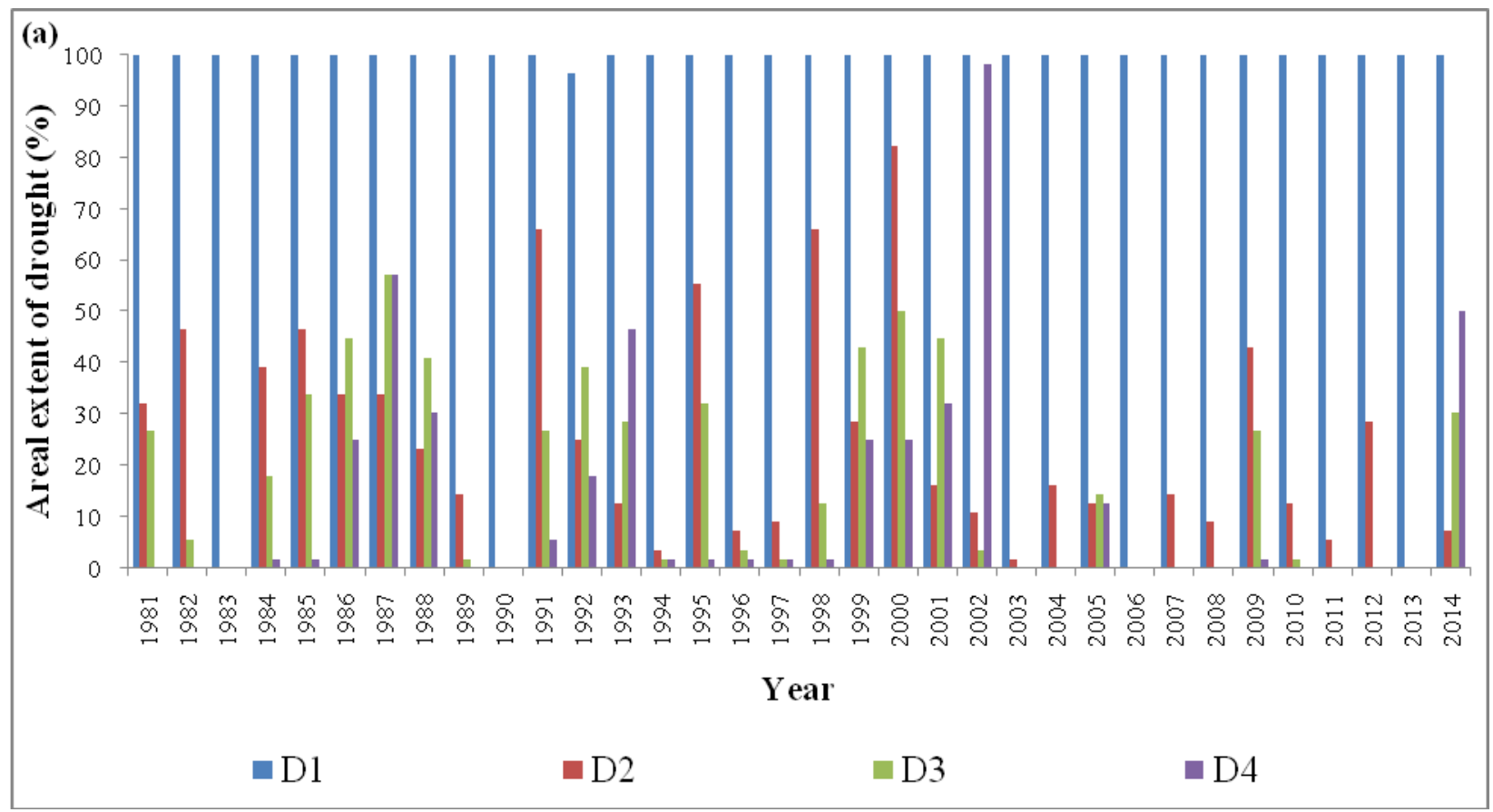

Fig.5 Areal extent of drought categories in 3-month time scale

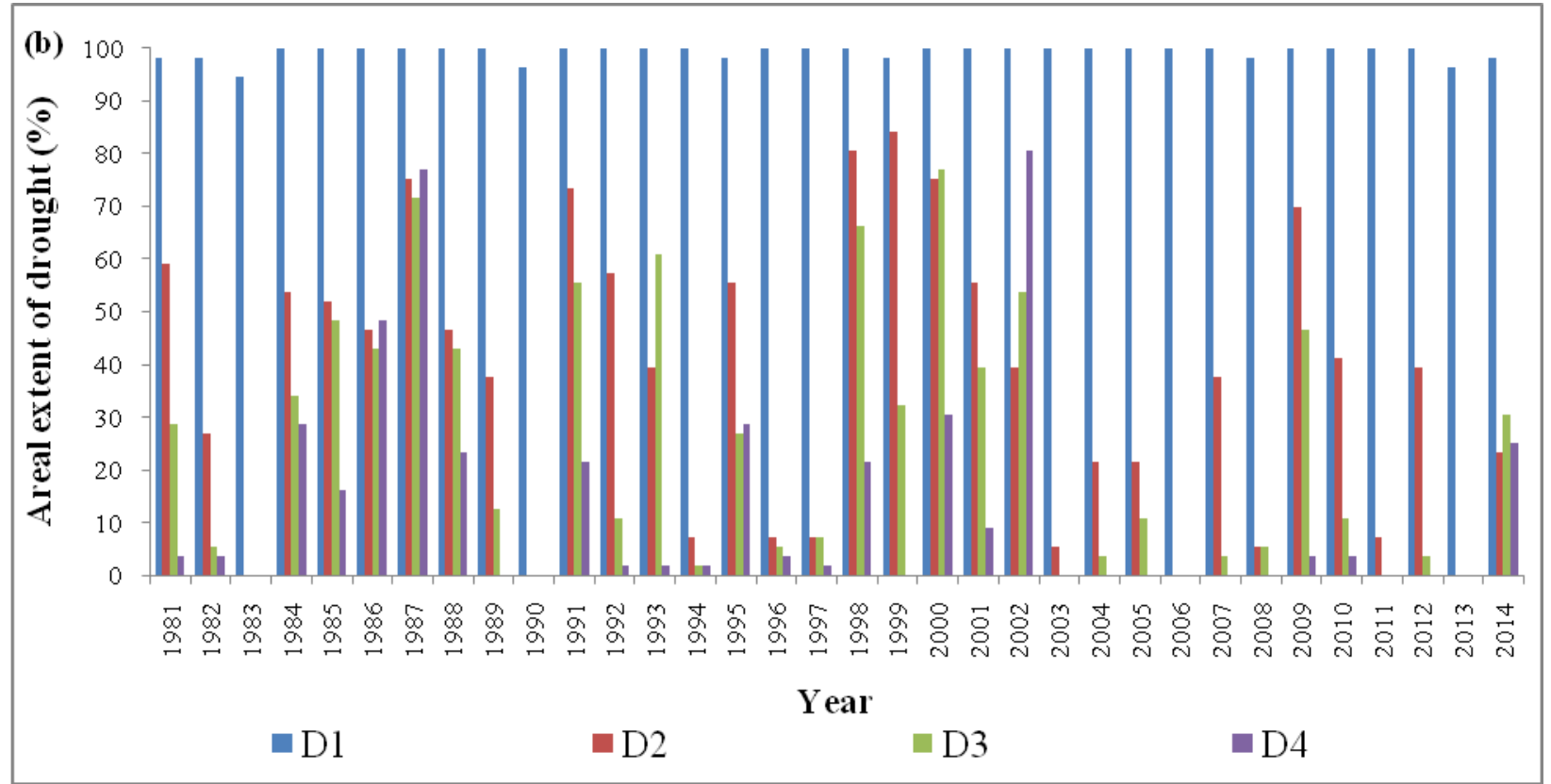

Further analysis showed that SPI_1 droughts were completely absent from November to March in the Mewar region. Monthly distribution of percentage of occurrence of drought at 3-month time scale showed that the negative SPI values occur most frequently during March, April and December followed by June, January and February. 


\section{Areal extent of annual drought categories}

Areal extent of drought for a particular year was computed using monthly SPI values for each grid. In this respect, number of grids which expressed mild, moderate, severe and extreme drought conditions at multiple time scales was determined for the corresponding SPI values and plotted for the study period to observe their areal extent (as percent of the total area of region) Percentage of area affected by different drought categories in each year during 1981-2014 at multiple time scale is given in the figures 4 and 5. For SPI_1 greater than 50 percent of the areas were affected by mild drought in the years 1991, 1998, 1995 and 2000. In 1987 and 2000 severe drought covered more than fifty percent of the region. The year 2002 was found worst year as about 98 percent of the total area of the region was under extreme drought condition, followed by the years 1987 and 2014 with more than 50 per cent of the total areas of the region was affected by extreme drought. For SPI_3, droughts in the years 1981 followed by 1984, 1985, 1987, 1991, 1999, 1998, 1992, 1995 and 2001 distributed in more than fifty percent of the Mewar region under moderate drought condition. 1991, 1993, 1998 and 2002 were affected 50 to 60 percent of the region under severe drought condition. 1987 and 2000was found to be the worst year, when about 75 per cent of the total area of the region was under extreme drought.

In conclusion, the present study attempts to identify the spatio-temporal extent of agricultural drought over Mewar region of Rajasthan. SPI is used as a drought indicator in this study and its found effective in analyzing the short term droughts, which cause significant impact on agriculture. Analysis indicated that region experienced short term droughts frequently during study period, in which mild droughts occur more frequently and extreme droughts occur least frequently. More than $50 \%$ of the areas were frequently affected by extreme and severe droughts during study period.

\section{Abbreviations}

USD - United States Dollar

GIS - Geographical Information System

IDW - Inverse Distance Weighting

DI - Drought Index

PDSI - Palmer Drought Severity Index

SPI - Standardized Precipitation Index

PN - Percent Normal

SWSI - Surface Water Supply Index

ADI - Aggregated Drought Index

NADI - Nonlinear Aggregated Drought Index

\section{Acknowledgement}

Author is thankful to Department Of Science And Technology, Ministry Of Science And Technology, New Delhi for financial support.

\section{References}

American Meteorological Society. 1997. Meteorological drought-policy statement. Bulletin of the American Meteorological Society, 78, 847-849.

Andreadis, K.M., Clark, E.A., Wood, A.W., Hamlet, A.F. and Lettenmaier, D.P. 2005. J. Hydrometeorol., 6: 985-1001.

Barua, S. 2010. Drought assessment and forecasting using a nonlinear aggregated drought index. Thesis submitted to Victoria University, Australia.

Belayneh, A. 2012. Short term and long term SPI drought forecasts using wavelet neural networks and wavelet support vector regression in the Awash River Basin of Ethiopia. Thesis submitted to Department of Bioresource Engineering, MacDonald Campus of McGill University. Canada.

Cacciamani, C., Morgillo, A., Marchesi, S. and Pavan, V. 2007. Water Sci. Technol. Library, 62(1): 29-48. 
Dutra, E., Giuseppe, F. Di., Wetterhall, F. and Pappenberger, F. 2013. Hydrol. Earth Syst. Sci., 17: 2359-2373.

Dutta, D., Kundu, A., Patel, N.R., Saha, S.K., Siddiqui, A.R. 2015. The Egyptian J. Remote Sensing and Space Sci., 18; 5363.

Edossa, D.C., Babel, M.S. and Gupta, A.D. 2010. Water Resour. Manage, 24: 1441-1460.

Gibbs, W.J. and Maher, J.V. 1967. Rainfall deciles as drought indicators, Bureau of Meteorology Bulletin No. 4, Commonwealth of Australia, Melbourne, Australia.

Hayes, M.J. 2003. Drought Indices. National Drought Mitigation Center. University of Nebraska-Lincoln.

Hisdal, H. and Tallaksen, L.M. 2003. J. Hydrol., 281(3): 230-247.

IDIC and NDMC. 1999. A Newsletter of the International Drought Information Center and the National Drought Mitigation Center Drought network news, 11(1): 1-23.

Jain, S.K., Keshri, R., Goswami, A., Sarkar, A. 2010. Nat. Hazards, 54: 643-656.

Keyantash, J. and Dracup, J.A. 2002. Bull. American Meteorol. Soc., 83(8): 11671180.

Keyantash, J.A. and Dracup, J.A. 2004. Water Res. Res., 40(9): 1-13.

Manikandan, M., and D. Tamilmani. 2015. J. Inst. Eng. India. Series, 177-184.

McKee, T.B., Doesken, N.J. and Kleist, J. 1993. American meteorological society Boston, 179-184.

Mishra, A.K. and Desai, V.R. 2005. Int. J. River Basin Manage., 3(1): 31-41.

Mishra, A.K. and Singh, V.P. 2010. J. Hydrol., 391(1-2): 202-216.

Murthy C.S. and Sesha Sai M.V.R. 2010, 'Agricultural Drought Monitoring and Assesment'. In Roy P.S, Dwivedi R.S and Vijayan D. Eds): "Remote Sensing Applications" (pp. 303-330. National
Remote Sensing Centre, Indian Space Research Organization, Department of Space, Government of India.

Nohegar, A., Heydarzadeh, M. and Malekian, A. 2013. Desert, 18(1): 79-87.

NRSC. 2008. 'Agricultural Drought'. National Remote Sensing Centre, Indian Space Research Organization, Department of Space, Government of India.

Palmer, W. 1965. Meteorological drought. Tech. Rep., U.S. Weather Bureau, Washington, D.C, 45, 1-58.

Rathore, B.M.S., Sud, R., Saxena, V., Rathore, L.S., Rathore, T.S., Subrahmanyam, V.G., and Roy, M.M. 2014. Drought Conditions and Management Strategies in India. Country Report prepared for the Regional Workshop for Asia-Pacific as part of the UN-Water Initiative on "Capacity Development to Support National Drought Management Policies" organized from 6-9th May 2014 in Hanoi, Vietnam, 1-7.

Rathore, M.S. 2004. State level analysis of drought policies and impacts in Rajasthan, India, Working paper 93, Drought Series, Paper 6, Int. Water. Manage. Inst.

Rathore, M.S. 2005. State level analysis of drought policies and impacts in Rajasthan, India. Colombo, Sri Lanka: IWMI. 40p. Working paper 93: Drought Series Paper, No (6).

Rathore, N.S. 2010. A Historical Perspective of the Development of Rain Water Harvesting Techniques in the Mewar Region, Udaipur, Rajasthan, India. Mountain Region of India. Conference Proceeding; 4th International Conference on Water Resources and Arid Environments 2010, Riyad, Kingdom of Saudi Arabia, pp: 429-438.

Rathore, N.S. 2011. Int. J. Water Res. Arid Environ., 1(4): 285-294. 
Rathore, N.S. and Verma, N. 2013. Int. J. Water Res. Arid Environ., 2(1): 45-50

Shafer, B.A., and Dezman, L.E. 1982. In Proceedings of the western snow conference in Reno, Nevada, USA, 50: 164-175.

Siddiqui, A.R. 2004. Regional Evaluation of Desertification Hazards in the Aridlands of Western Rajasthan (an unpublished Ph. D. thesis. AMU, Aligarh, Uttar Pradesh, India, pp. 221.
Willeke, G., Hosking, J.R., Wallis, J.R., Guttman, N.B. 1994. The national drought atlas. Institute for water resources report, 94-NDS-4.

WMO. 2012. Standardized Precipitation Index User Guide 1-16.

Yevjevich, V. 1967. Objective approach to definitions and investigations of continental hydrologic droughts. Hydrology Paper 23. Colorado State University, Fort Collins, Colorado, USA.

\section{How to cite this article:}

Basamma, K.A., R.C. Purohit, S.R. Bhakar, Mahesh Kothari, R.R. Joshi, Deepak Sharma, P.K. Singh and Mittal, H.K. 2017. Analysis of Short-Term Droughts in the Mewar Region of Rajasthan by Standard Precipitation Index. Int.J.Curr.Microbiol.App.Sci. 6(6): 182-192. doi: https://doi.org/10.20546/ijcmas.2017.606.022 